\title{
'I once wore an angry bird t-shirt and went to read Qur'an': asymmetrical institutional complexity and emerging consumption practices in Pakistan
}

Article

Supplemental Material

Figure 1

Husain, S., Molesworth, M. and Grigore, G. (2019) 'I once wore an angry bird t-shirt and went to read Qur'an': asymmetrical institutional complexity and emerging consumption practices in Pakistan. Marketing Theory, 19 (3). pp. 367-390. ISSN 1741-301X doi:

https://doi.org/10.1177/1470593118821717 Available at https://centaur.reading.ac.uk/79048/

It is advisable to refer to the publisher's version if you intend to cite from the work. See Guidance on citing.

To link to this article DOI: http://dx.doi.org/10.1177/1470593118821717

Publisher: Sage

All outputs in CentAUR are protected by Intellectual Property Rights law, including copyright law. Copyright and IPR is retained by the creators or other copyright holders. Terms and conditions for use of this material are defined in the End User Agreement. 


\section{www.reading.ac.uk/centaur}

\section{CentAUR}

Central Archive at the University of Reading

Reading's research outputs online 


\section{Figure 1: Aymetrical Institution logics and what Pakistani Tweens Wear}

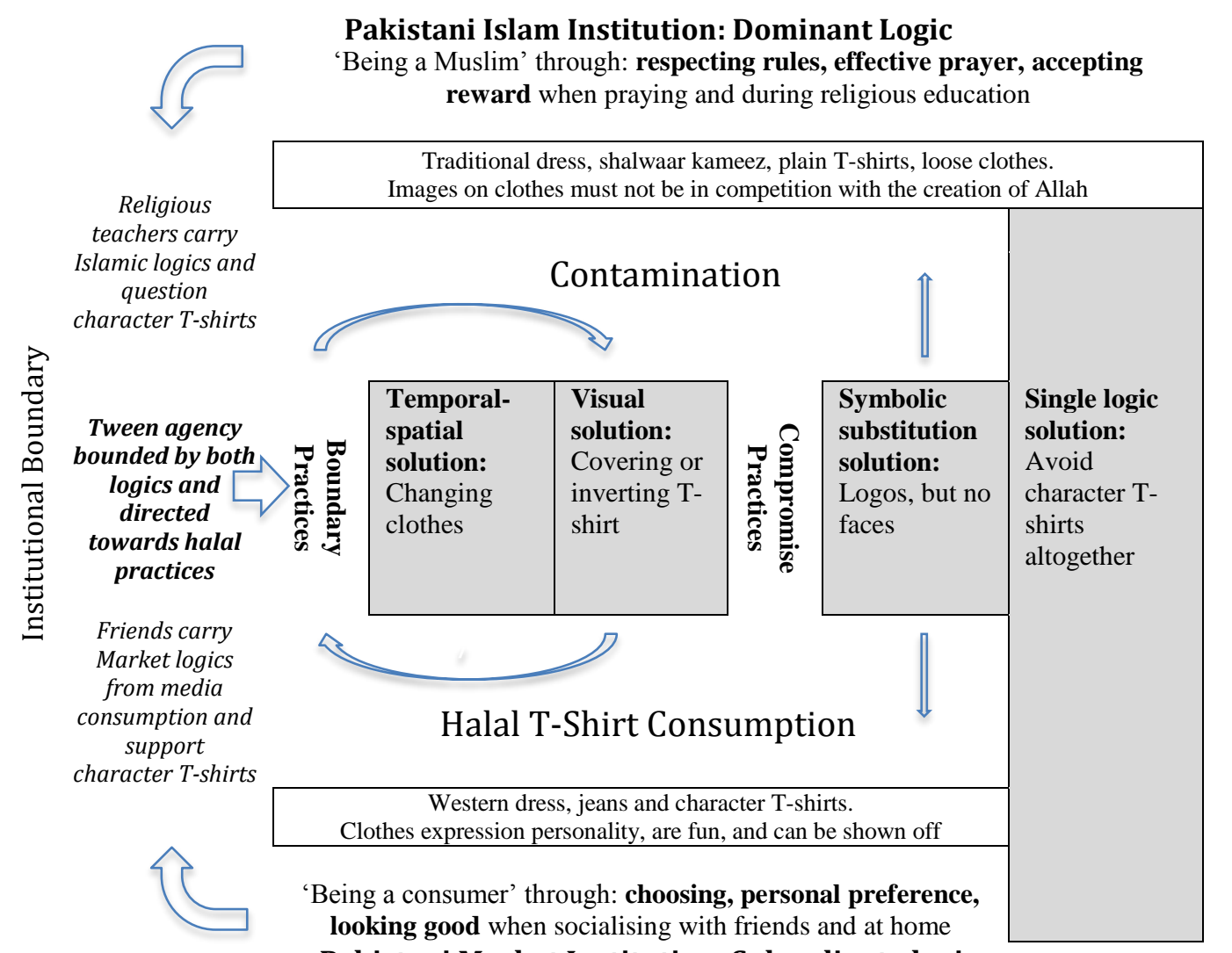

